\title{
Improved Teacher Understanding of Classroom Action Research at SMP Negeri 1 Bungoro, Pangkep Regency
}

\section{Peningkatan Pemahaman Guru tentang Penelitian Tindakan Kelas di SMP Negeri 1 Bungoro Kabupaten Pangkep}

\author{
Yusniar Rasjid*, Muqtakdir Nurfalaq, Moh. Mulyadi Prasetyoa, Kamriana S. \\ Departmen of Biology Ecucation, STKIP Pembangunan Indonesia, Makassar, Indonesia
}

\begin{abstract}
Social Service in SMP Negeri 1 Bungoro, located in Pangkep Regency, South Sulawesi. The problem of partners is that teachers still have difficulty planning and implementing Classroom Action Research. An alternative solution to the problem is to provide Classroom Action Research Training to the teachers of SMP Negeri 1 Bungoro, Pangkep Regency. The output target to be achieved is the skill of the teachers of SMP Negeri 1 Bungoro, Pangkep Regency in compiling a Classroom Action Research proposal so that it can improve the quality of learning. The method to be carried out is the presentation of material on classroom action research in PowerPoint displayed on the LCD. From the results of the activities that have been carried out, it is found that there is an increase in the ability of teachers in preparing Classroom Action Research Proposals.
\end{abstract}

\begin{abstract}
Abstrak
Pengabdian ini dilakukan di SMP Negeri 1 Bungoro yang terletak di Kabupaten Pangkep Sulawesi Selatan. Permasalahan mitra yaitu para guru masih kesulitan dalam merencanakan dan melaksanakan Penelitian Tindakan Kelas. Alternatif solusi masalah yaitu memberikan Pelatihan Penelitian Tindakan Kelas kepada para guru SMP Negeri 1 Bungoro Kab Pangkep. Adapun target luaran yang ingin dicapai yaitu terampilnya para guru SMP Negeri 1 Bungoro Kab Pangkep dalam menyusun proposal Penelitian Tindakan Kelas sehingga dapat meningkatkan kualitas pembelajaran. Metode yang akan dilakukan yaitu presentasi Materi tentang Penelitian Tindakan Kelas dalam Power Point yang ditampilkan melalui LCD. Dari hasil kegiatan yang telah dilakukan diperoleh adanya peningkatan kemampuan guru dalam Menyusun Proposal Penelitian Tindakan Kelas.
\end{abstract}

(C) 2020 Author(s).

Keywords:Classroom Action Research, Sosial Service.

\section{Pendahuluan}

Penelitian Tindakan Kelas (PTK) sangat penting untuk dilakukan oleh para guru sebagai upaya pemecahan masalah dan peningkatan mutu di berbagai bidang. PTK dilakukan dengan diawali oleh suatu kajian terhadap masalah secara sistematis (Suharsimi, Suhardjono, \& Supardi, 2008). Hal kajian ini kemudian dijadikan dasar untuk mengatasi masalah tersebut. Dalam proses pelaksanaan rencana yang telah disusun, kemudian dilakukan suatu observasi dan evaluasi yang dipakai sebagai masukan untuk melakukan refleksi atas apa yang terjadi pada tahap pelaksanaan. Hasil dari proses refleksi ini kemudian melandasi upaya perbaikan dan peryempurnaan rencana tindakan berikutnya.

\footnotetext{
* Corresponding author:

E-mail address: yusniar.rasjid@gmail.com (Yusniar Rasjid)
} 
Tahapan-tahapan di atas dilakukan berulang-ulang dan berkesinambungan sampai suatu kualitas keberhasilan tertentu dapat tercapai (Kusuma \& Dwitagama, 2010).

PTK yang dilakukan oleh guru dapat menjadi model bagi siswa dalam meningkatkan prestasinya. Guru yang selalu melakukan PTK yang inovatif dan kreatif akan memiliki sikap kritis dan reflektifterhadap hasil belajar yang dicapai siswa. Sikap kristis inilah yang akan dijadikan model bagi siswa untuk terus merefleksi diri sebagaimana yang dilakukan oleh gurunya (Wiriatmadja, 2005).

Beberapa manfaat PTK bagi guru antara lain:

1. Guru memiliki kemampuan memperbaiki proses pembelajaran melalui suatu kajian yang mendalam terhadap apa yang terjadi dikelasnya. Keberhasilan dalam perbaikan ini akan menimbulkan rasa puas bagi guru, karena Ia telah melakukan sesuatu yang bermanfaat bagi siswanya melalui proses pembelajaran yang dikelolanya.

2. Dengan melakukan PTK, guru dapat berkembang dan meningkatkan kinerjanya secara profesional, karena guru mampu menilai, merefleksi diri, dan mampu memperbaiki pembelajaran yang dikelolanya. Dalam hal ini, guru tidak lagi hanya sebagai seorang praktisi yang sudah merasa puas terhadap apa yang dikerjakan selama ini, namun juga sebagai peneliti dibidangnya yang selalu ingin melakukan perbaikan-perbaikan pembelajaran yang inovatif dan kreatif.

3. Melalui PTK, guru mendapat kesempatan untuk berperan aktif dalam mengembangkan pengetahuan dan keterampilan sendiri. Guru tidak hanya menjadi penerima hasil perbaikan dari orang lain, namun guru itu sendiri berperan sebagai perancang dan pelaku perbaikan tersebut, sehingga diharapkan dapat menghasilkan teori-teori dan praktik-praktik pembelajaran.

Dengan PTK, guru akan merasa lebih percaya diri. Guru yang selalu merefleksi diri, melakukan evaluasi diri, dan menganalisis kinerjanya sendiri di dalam kelas, tentu saja akan selalu menemukan kekuatan, kelemahan, dan tantangan pembelajaran dan pendidikan masa depan, dan mengembangkan alternatif pemecahan masalah kelemahan yang ada pada dirinya dalam pembelajaran. Guru yang demikian adalah guru yang memiliki kepercayaan diri yang kuat (Widayati, 2008).

Dalam bidang pendidikan, khususnya kegiatan pembelajaran, PTK berkembang sebagai suatu penelitian terapan.PTK sangat bermanfaat bagi guru untuk meningkatkan mutu proses dan hasil pembelajaran di kelas. Dengan melaksanakan tahap-tahap PTK, guru dapat menemukan solusi dari masalah yang timbul di kelasnya sendiri, bukan kelas orang lain (McNiff, 1992), dengan menerapkan berbagai ragam teori dan teknik pembelajaran yang relevan secara kreatif. Selain itu sebagai penelitian terapan, disamping guru melaksanakan tugas utamanya mengajar di kelas, tidak perlu harus meninggalkan siswanya. Jadi PTK merupakan suatu penelitian yang mengangkat masalah-masalah aktual yang dihadapi oleh guru di lapangan. Dengan melaksanakan PTK, guru mempunyai peran ganda : praktisi dan peneliti (Mulia \& Suwarno, 2016).

\section{Metode}

Pemberian Materi: Pada tahap ini Pemateri menyajikan materi Penelitian Tindakan Kelas ini dalam bentuk powerpoint. Penjelasan diawali dengan pengetahuan umum tentang karya ilmiah dan karya nonilmiah. Kemudian dilanjutkan dengan materi PTK secara khusus ( Pengertian, model, langkah-langkah, prosedur pelaksanaan, dan manfaat PTK bagi guru)

Tanya Jawab: Setelah menyajikan materi kami memberikan kesempatan kepada peserta untuk mengajukan pertanyaan. Pertanyaan tentang penyusunan proposal, masalah yang dihadapi pada saat pelaksanaan penelitian dan lain-lainnya.

Penyusunan Proposal Penelitian Tindakan Kelas: Ini adalah tahap akhir dari Workshop ini yaitu terampilnya para guru dalam menyusun proposal PTK. Kami membimbing penyusunan proposal PTK ini secara daring. 


\section{Hasil dan Diskusi}

Sesuai dengan jadwal pelatihan, pelatihan dibuka secara resmi oleh Ketua pelaksana kegiatan di Ruang serba guna SMP Negeri 1 Bungoro Kabupaten Pangkep. Acara Pembukaan berlangsung meriah dengan peserta pelatihan memberikan ucapan terima kasih atas respon yang ditunjukkan oleh guru-guru dan tenaga kependidikan lainnya dalam mengikuti pelatihan. Pada materi pertama tentang metodologi penelitian pemateri memaparkan materinya tentang metodologi penelitian dan peserta menyimak penjelasan materi tersebut. Pada materi kedua tentang Metodologi penelitian tindakan kelas pemateri memaparkan materi tentang karakteristik, prasyarat PTK, unsur-unsur sasaran/objek PTK dan Prosedur pelaksanaan Penelitian tindakan kelas dan peserta ,menyimak penjelasan materi tersebut. Pada materi ketiga tentang Aplikasi penelitian tindakan kelas pemateri memaparkan contoh penelitian tindakan kelas serta memperlihatkan sistematika penyusunan penelitian tindakan kelas, setelah pemateri memaparkan materi pserta dipandu dalam praktek dalam penyusunan penelitian tindakan kelas. Setelah materi ketiga selanjutnya adalah penutupan untuk kegiatan yang dilaksanakan selama tiga hari ini.

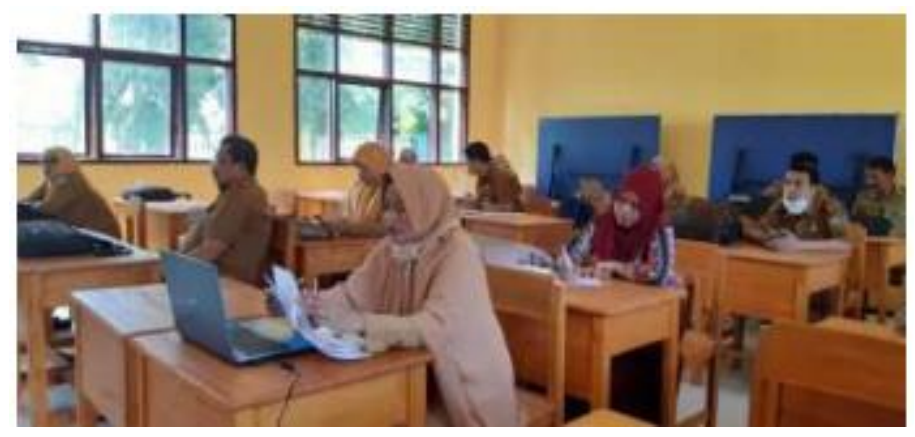

Fig. 1. Peserta Serius mengikuti Pelatihan

Presentasi hasil pembuatan proposal Penelitian Tindakan Kelas oleh masing-masing kelompok peserta pelatihan dilaksanakan pada tanggal 16-18 Mei 2020. Hasil cetak proposal dan power point sudah disiapkan oleh masingmasing kelompok dengan baik walaupun waktu penyusunannya hanya 4 hari. Hal tersebut menunjukkan semangat guru yang tinggi dalam kegiatan ini. Masing-masing kelompok diwakili 2 orang langsung mempresentasikan proposal PTK di depan tim PPM dan semua guru-guru peserta pelatihan. Dalam kegiatan ini banyak sekali diskusi yang terjadi diantara guru maupun tim PPM, dan diakhir kegiatan diberikan masukan-masukan oleh tim PPM terkait isi, tata tulis dan sebagainya sehingga proposal PTK yang disusun oleh kelompok-kelompok guru menjadi lebih baik lagi

Setelah penutupan pelatihan ini peserta masih diberikan kesempatan untuk melakukan bimbingan secara langsung bagi yang memiliki kendala penyusunan penelitian tindakan kelas. Dengan metode seperti itu diharapkan dapat mengakomodasi guru untuk melakukan konsultasi penyusunan penelitian tindakan kelas bilamana guru mengalami kesulitan. Program pelatihan penelitian tindakan kelas untuk guru-guru SMP Negeri 1 Bungoro Kabupaten Pangkep dengan jadwal dilakukan selama 1 hari, mulai dari persiapan hingga evaluasi hasil kegiatan.

\section{Kesimpulan}

Dari kegiatan pelatihan penelitian tindakan kelas di SMPN 1 Bungoro, dapat disimpulkan bahwa: Melalui kegiatan ini telah meningkatkan pengetahuan dan pemahaman Guru tentang PTK, Guru telah mampu menyusun proposal Penelitian Tindakan Kelas 


\section{Acknowledgements}

Penulis mengucapkan terima kasih kepada STKIP Pembangunan Indonesia dan terkhusus kepada SMP Negeri 1 Bungoro Kabupaten Pangkep,yang telah memberikan izin kepada kami untuk melaksanakan kegiatan pengabdian ini.

\section{References}

Kusuma, W., \& Dwitagama, D. (2010). Mengenal Penelitian Tindakan Kelas. Jakarta: PT. Indeks.

McNiff, J. (1992). Action Research: Principle and Practice. London: Routledge.

Mulia, D. S., \& Suwarno. (2016). PTK (Penelitian Tindakan Kelas) dengan Pembelajaran Berbasis Kearifan Lokal dan Penulisan Artikel Ilmiah di SD Negeri Kalisube, Banyumas. Khazanah Pendidikan.

Suharsimi, A., Suhardjono, \& Supardi. (2008). Penelitian Tindakan Kelas. Jakarta: Bumi Aksara.

Widayati, A. (2008). Penelitian Tindakan Kelas. Jurnal Pendidikan Akuntansi Indonesia, 87-93.

Wiriatmadja, R. (2005). Metode Penelitian Tindakan Kelas. Bandung: Rosda Karya. 